\title{
THE BENTHIC MACROFAUNA OF SLUDGE-AFFECTED SEDIMENTS IN THE DERWENT ESTUARY, SOUTHERN TASMANIA
}

\author{
by Pierre Horwitz and Greg Blake
}

(with two tables and three text-figures)

\begin{abstract}
HORWITZ, P. \& BIAKE, G., 1992: (31:x): The benthic macrofauna of sludge-affected sediments in the Derwent estuary, southern Tasmania. Pap. Proc. R. Soc. Tasm. 126: 67-72. https://doi.org/10.26749/rstpp.126.67 ISSN 0080-4703. Centre for Environmental Studies, University of Tasmania, GPO Box 252C, Hobart, Tasmania, Australia 7001.
\end{abstract}

\begin{abstract}
The paper reports the findings of an extensive survey of benthic invertebrates from the Derwent estuary in southern Tasmania, sampled during an investigation into the distribution and character of sludge emanating from a pulp and paper factory. In total, 45 invertebrate species were collected, but none was found in the sediment in the river channel between the pulpmill (its effluent outfall) and a site $5 \mathrm{~km}$ downstream. Similarly, other sediments with wood fibre present (measured by loss on ignition) and with very negative redox values were faunistically depauperate and possessed much lower species richness than that anticipated from other studies in Australia. The sediments in shallow areas in the middle part of the estuary had very high densities of invertebrates and had less mechanical wood fibre than sediments in deeper water nearby or other sediments further downstream. These results suggest that smothering by wood fibre, with concomitant toxicological effects of chemical reactions in the sediment, results in the low invertebrate diversities observed. These findings must be tempered by the methodological limitations involved with the selection of sample sites and lack of seasonal data, which have prevented definitive statements from being made about the level of environmental stress being experienced in the lower parts of the estuary.
\end{abstract}

Key Words: benthic macrofauna, sludge, estuary, Tasmania.

\section{INTRODUCTION}

The Derwent River is one of the largest river systems in Tasmania, arising in the wetter, western portion of the Central Highlands and flowing in a southeasterly direction to its estuary, on which Hobart is situated. Here, the estuary is regarded as a "highly stratified salt-wedge/partially mixed estuarine system ..." (Davies \& Kalish 1989). The saltwedge moves backwards and forwards over approximately $10 \mathrm{~km}$ of the upper estuary, depending on the freshwater inflows. At the inland extension of the salt-wedge, ? pulp and paper manufacturer, Australian Newsprint Mills Ltd (ANM), has its effluent outfall, and in the past huge quantities of mechanical wood fibre and other organic materials have flowed from this source. Further downstream, beyond the area of salt-wedge movement, two other major industries have their effluent inputs, namely a chocolate factory and a zinc refinery. Over the length of the estuary, about a dozen sewerage plants have their outlets, and numerous stormwater drains empty into it, mainly via the rivulets. Concerns for its environmental quality were highlighted by a heavy metal concentration study, which led to claims of heavy contamination (Bloom \& Ayling 1977). These concerns have continued to be raised and were greatly exacerbated in late 1988 by the occurrence of rafts of foul-smelling organic material floating downriver and depositing on foreshore areas (Anon. 1989); this material is now referred to as "sludge" and its appearance on the householders' doorstep prompted government- and industry-sponsored research (Anon. 1989; this study).

In the past, marine benthic invertebrate communities have been used as indicators of environmental stress (e.g. Gray 1981 and Warwick 1986), but rarely has this type of work been applied to estuaries. One reason for this is that estuaries are areas of stress for aquatic faunas, due to problems of osmotic regulation resulting from the large seasonal and tidal fluctuations in salinity (Kennish 1990). The result is a biota which is both resilient and opportunistic (McComb \& Lukatelich 1986), with a characteristically patchy (in local distribution) macrofauna (Kennish 1990). Previous studies of estuarine benthic invertebrate faunas in Australia have covered urban areas (e.g. the Yarra River in Victoria Poore \& Kudenov 1978), suburban or largely agricultural estuaries (e.g. Poore 1982 - the Gippsland Lakes in Victoria; Jones et al. 1986 and Jones 1987 - the Hawkesbury system in NSW; Rainer 1981 - Port Hacking, NSW) or undisturbed estuaries (e.g. Edgar 1990 - the Port Davey/Bathurst Harbour estuary in Tasmania). All studies show patterns of invertebrate occurrences and densities with fluctuations in salinity, depth, substrate structure, temperature and other environmental parameters.

Detailed studies of the benthic invertebrate fauna of the Derwent estuary have not taken place; so far, studies have either concentrated on single species or groups, concentrating neither on the invertebrate ecology nor the impact of major environmental influences in the area, resulting in a lack of systematic surveys. Accordingly, the articles by Guiler (1955), and Spratt (1976) are limited in their usefulness. The most substantive study undertaken previously was that reported by Matthews (1979), in which 31 benthic species were recorded from samples taken over about a year in the upper estuary, but the "...unbalanced structure of the benthic data suggest(ed) a very stressed community ...”.

The present study aims not only to document the benthic invertebrate fauna in sludge-affected areas, but also to identify the most likely factors which influence the distribution and abundance of that fauna. 


\section{MATERIALS AND METHODS}

An Eckman Grab benthos sampler $(0.15 \times 0.15 \times 0.15 \mathrm{~m})$ was used to collect samples of sediment. Sixty-nine locations were sampled during a programme designed to determine the distribution and character of sludge in the Derwent Estuary (see Garland et al. 1990). The locations are shown in figure 1.

Samples were collected berween 0800 and 1600 hrs on the following days in 1990 (number of samples in parentheses): 21 Feb. (5), 22 Feb. (3), 2 Mar. (1), 6 Mar. (3), 7 Mar. (6), 8 Mar. (10), 9 Mar. (5), 19 Mar. (8), 20 Mar. (23) and 30 Mar. (5). More details about the locations, times and dates of the sampling are given in Garland et al. (1990).

At each sampling station, the depth of the water column was measured and adjusted to take into account the tidal variations in water height. The physicochemical parameters of $\mathrm{pH}$, conductivity and redox potential were determined by placing respective probes (WTW instrumentation) into the sediment as soon as it was released by the grab.

At each site, three grab samples were taken and amalgamated into a large plastic bag, resulting in approximately $3 \mathrm{~kg}$ of sediment.

Samples were preserved immediately by the application of concentrated formalin to make a solution of approximately $10 \%$, after which they were stored in plastic bags and transported to the laboratory. Each sample was washed through a sieve of $500 \mathrm{~mm}$ mesh pore size to remove clay and silt and the material remaining in the sieve was then transferred to a white-background tray where it was carefully sorted. Animal material was picked out and placed in a solution of $70 \%$ ethanol. A reference collection of all species identified in the samples was made with the assistance of taxonomic experts for some groups (see Acknowledgements). (This collection will be lodged in the Tasmanian Museum and Art Gallery.)

The number of species found in each sample (species richness), or the number of individuals of each species (total abundance) in each sample were then plotted against the following parameters to examine the data for linear trends: (i) conductivity (as a measure of salinity), redox potential and $\mathrm{pH}$;

(ii) distance from Boyer as estimated from a map (Tasmap 1:25 000, Lands Department, Hobart) (by adding incrementally the distance from the previous relevant sampling station);

(iii) depth of water column at medium low tide;

(iv) organic content (as determined by \% loss on ignition [LOI] at $550^{\circ} \mathrm{C}$ for two hours after initial drying at $110^{\circ} \mathrm{C}$ ); and

(v) \% clay (=\% kaolinite $+\%$ illite), and \% quartz (determined by Fourier transform-infrared spectroscopy; see Garland $e t$ al. 1990)

Where relevant, parameters were transformed from percent to arcsin values for the determination of correlation

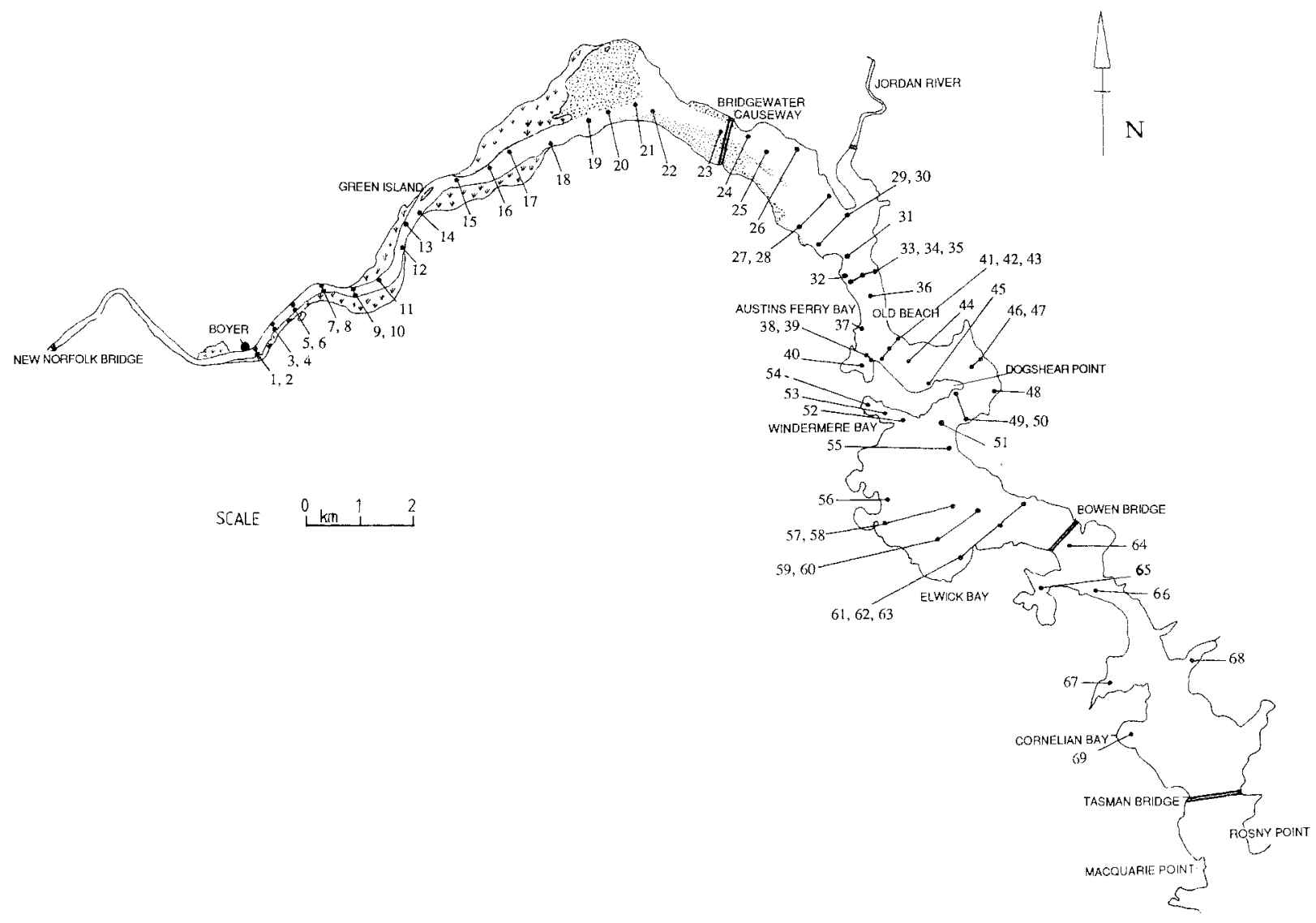

Fig. 1 - The Denwent estuary showing the location of the 69 sampling sites (•) with their code numbers, where detailed invertebrate analyses were undertaken. 
coefficients and their significance levels (Zar 1974), using the statistical package Statworks.

\section{RESULTS}

A total of 45 invertebrate and one vertebrate species was collected from the benthic samples (table $1 ;$ n.b. the number quoted is less than the " 52 " quoted in Garland et al. 1990, because of more detailed taxonomic study). None of the species could be regarded as belonging strictly to freshwater habitats, with the possible exception of chironomid (nonbiting midge) larvae, and these were only found in samoles in shallow water near Limekiln Point (table 1 and fig. 1). The most distant (from Boyer) samples contained several examples of predominantly marine species, such as the modocopid ostracods, polynoid polychaetes, nemerteans and sipunculans. The remaining species occurred commonly, sporadically or rarely throughout the estuarine area.

Two species were common and occurred in most samples, namely the spionid polychaete worm Orthoprionospio cirriformia and the bivalve mollusc (Arthritica helmsi). Both species were extremely abundant in a few samples; for instance, in sample 25 , a total of 428 individuals of the former species, and 332 individuals of the latter, were found. These maximum densities corresponded to 6341 and 4919 individuals per $\mathrm{m}^{2}$. Three other species, two of them amphipod crustaceans (Paracorophium sp. and Limnoporeia kingi), and one gastropod mollusc (Tatea rufilabris) were the next most commonly encountered species in the samples.

Species richness ranged from 0 (no animals in the sample) to 22 (table 1; samples with no animals not included). All of the samples from the area between the ANM outfall at Boyer and $5 \mathrm{~km}$ downstream, in the so-called mixing zone, contained no fauna. The number of species found in each sample generally increased with distance downstteam (fig. 2), so that the sample with the most species came from Cornclian Bay, the site which was both furthest from the source of mechanical wood fibre and closest to full marine conditions. These relationships are confirmed by the highly significant correlations between species richness and redox potential, and between species richness and LOI (table 2), because LOI in effect measures the amount of wood fibre in a sample, and the anaerobic conditions produced by wood fibre breakdown are reflected by lower (more negative) redox values.

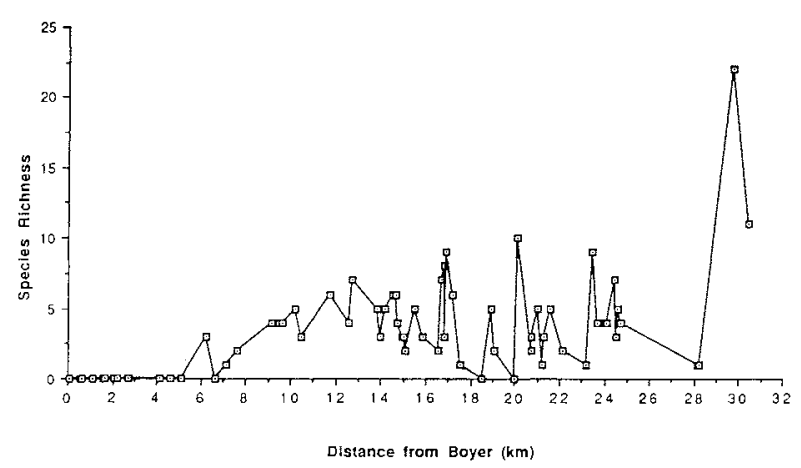

Fig. 2 -- The number of species found in sediment samples as a function of distance from Boyer (the effluent outfall).
The highly significant correlation between $\mathrm{pH}$ and species richness (table 2) can also be explained by a combination of these relationships, so that

(i) sediments become more alkaline with an increasing marine influence in an estuary, and the distance relationship described above for species richness might simply correlate with other variables (like $\mathrm{pH}$ ) which vary over distance; and (ii) sediments become more acidic as organic material breaks down, releasing humic acids; the relationship between $\mathrm{pH}$ and species richness therefore reflects the species richness/ LOI relationship and the presence of mechanical wood fibre in samples.

The total abundance of animals showed a similar pattern to the species richness in the mixing zone, where no, or very little fauna occurred up to $7.5 \mathrm{~km}$ from Boyer (fig. 3). However, a diffetent pattern emerged downstream of the mixing zone (fig. 3), where major peaks in abundance occurred in sampling stations on either side of the Bridgewater causeway. These peaks appear to be associated with shallower areas where waters are of a lower salinity, since total abundance is significantly negatively correlated with both conductivity and depth (table 2); the shallower the water, and the lower the conductivity/salinity, the higher the total abundance (and vice versa). This relationship may also be influenced by an apparent absence of wood fibre, as evidenced by the very low values of LOI found for the shallow samples 25, 26, 27 and 29, where abundances were the highest found in the survey (table 1), and confirmed by the highly significant negative correlation between total abundance and LOI.

\section{DISCUSSION}

A comparison of the Derwent estuary macrobenthic fauna found in this survey with that of other estuarine faunas demonstrates some conspicuous differences. The most profound of these is that only 45 invertebrate species were located in the Derwent compared with 248 species in the Yarra system (Poore \& Kudenov 1978), 90 in the Gippsland Lakes region (Poore 1982), 340 in the Port Davey estuary (Edgar 1990), and 177 species in the Hawkesbury estuary (Jones 1987). These differences may be attributable to one or more of the following factors:

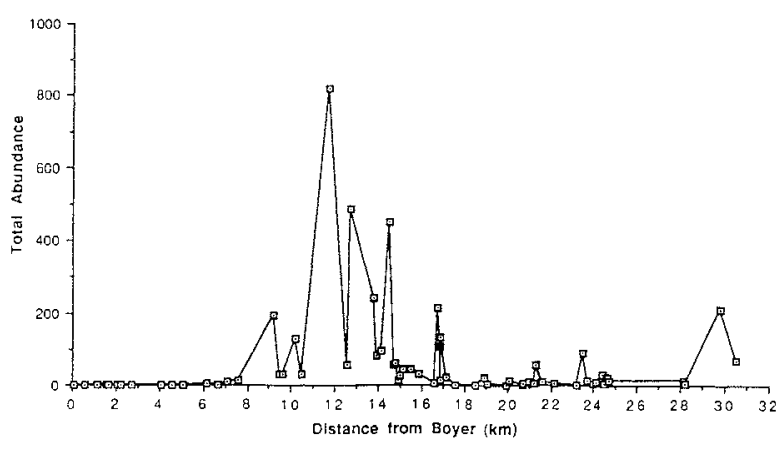

Fig. 3 - The total number of individuals found in sediment samples as a function of distance from Boyer (the effluent outfall). 
Table 1

Macrofauna of sediment in the Derwent Estuary

Shows the sampling stations where invertebrate species were found, along with the number of individuals of each species at each site. Results from sampling stations with no invertebrates, and stations where two or less species occurred with a total abundance of five or less, are not presented here $($ where $\mathrm{C}=$ colony)

\begin{tabular}{|c|c|c|c|c|c|c|c|c|c|c|c|c|c|c|c|c|c|c|c|c|c|c|c|c|c|c|c|c|c|c|c|c|c|c|c|c|c|c|c|c|c|c|}
\hline Taxonomic Unic & 15 & 18 & 19 & 20 & 21 & 22 & 23 & 24 & 25 & 26 & 27 & 28 & 29 & 30 & 31 & 32 & 33 & 34 & 35 & 36 & 37 & 38 & 39 & 40 & 41 & 43 & 47 & 49 & 51 & 52 & 54 & 55 & 58 & 59 & 60 & 61 & 62 & 63 & 64 & 65 & 68 & 69 \\
\hline HYDROZOA sp. or spp & & & & & & & & & & & & & & & & & & & & & & & & & & & & c & & & & & & & & & & & & & & \\
\hline $\begin{array}{l}\text { NEMERTEA sp. } 1 \\
\text { NEMERTEA sp. } 2\end{array}$ & & & & & & & & & & & & & & & & & & & & & & & & & & & & & & & & & & l & 1 & & & & 2 & 1 & 9 & $\begin{array}{l}16 \\
1\end{array}$ \\
\hline $\begin{array}{l}\text { NEMATODA sp. or spp } \\
\text { NEMARA }\end{array}$ & & & & & & & & & & & & & & & & & & & & & & & & & & & & & & & & & & & & 1 & & & & & & 2 \\
\hline TRICLADIDA sp. 1 & & & & & & & & & & & & & & & & & & & & & & & & & & & & 1 & & & & & & & & 10 & & & & & & 1 \\
\hline TRICLADIDA sp. 2 & & & & & & & & & & & & & & & & & & & & & & & & & & & & & & & & & & & & & & & & & & 2 \\
\hline SIPUNCULIDA sp. or spp. & & & & & & & & & & & & & & & & & & & & & & & & & & & & & & & & & & & & & & & & & 1 & 1 \\
\hline OLIGOCHAETA sp. 1 & & & & & & & & & & 4 & & & & & & & & & & & & & & & & & & & & & & & & & & & & & & & & \\
\hline $\begin{array}{l}\text { POLYCHAETA } \\
\text { Polydora sp. }\end{array}$ & & & & & & & & & & & & & & & & & & & & & & & & & & & & & & & & & & & & & & & & 1 & & 70 \\
\hline $\begin{array}{l}\text { Orthooprionospio cimiformia } \\
\text { Ortopros }\end{array}$ & 1 & 10 & 172 & & 125 & 19 & 14 & 50 & 428 & 154 & 198 & 22 & 6 & 51 & 18 & 3 & & 12 & 7 & & 19 & 14 & 12 & 6 & 2 & 1 & 2 & & 1 & 3 & & & 4 & 2 & 3 & 12 & 5 & 1 & 4 & 1 & & in \\
\hline Boccardiella sp. & & & & & & & & & & & & & & & & & & & & & & 1 & & & & & & & & & & & & & & & & & & & & 1 \\
\hline $\begin{array}{l}\text { Spio sp. } \\
\text { Caspitellusp./Capitellides sp. }\end{array}$ & 1 & & 12 & 6 & 1 & 1 & 2 & & & & & & & & 1 & & & 2 & & & & 1 & & 2 & & & 2 & & & & & & & & & 5 & & 5 & & & 29 & 33 \\
\hline $\begin{array}{l}\text { Cirratulidae sp. } 1 \\
\text {. }\end{array}$ & & & & & & & & & & & & & & & & & & & & & & & & & & & & & & & & & & & & & & & & & 8 & 3 \\
\hline $\begin{array}{l}\text { PLatgnereis australia } \\
\text { A ustraloneresis ehlersi }\end{array}$ & & & & & & & & 1 & 1 & 1 & & & & 1 & & & & & & & & & & & & & & & & & & & & & & & & 5 & & & & 1 \\
\hline 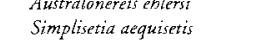 & & & & & & & & & & & 2 & & & & & & & & & & & & I & 3 & & & & & & 1 & 1. & & & 1 & 2 & & & & & & & 1 \\
\hline Simplisetia amphidonta & & & & & 1 & & & & & & & & & & & & & & & & & 1 & & & & & & & & & & & & & & & & & & & & 1 \\
\hline Lumbrineris sp. & & & & & & & & & & 2 & & & & & & & & & & & 1 & 1 & & & 2 & & 4 & & & & & 5 & 2 & & 4 & 7 & 10 & & & & 2 & \\
\hline Lysilla sp. & & & & & & & & & & & & & & & & & & & & & & & & & & & & & & & & & & & & & & & & & & 10 \\
\hline Euchone sp. & & & & & & & & & & & & & & & & & & & & & & & & & & & & 1 & & & & & & & & 10 & & & 5 & & & 1 \\
\hline Harmathoe prteclara & & & & & & & & & & & & & & & & & & & & 1 & & & & & & & & 1 & & & & & & & & & & & 1 & & 2 & 5 \\
\hline Leitoscoloplos bifuercatus & & & & & & & & & & & & & & & & & & & & & & & & & & & & & & & & & & & & & & & & & 1 & \\
\hline PFlabelligeridae s. 1 & & & & & & & & & & & & & 1 & & & & & & & & & & & & & & & & & & & & & & & & & & & & & \\
\hline Unidentificd Polychaete & & & & & & & & & & & & & 1 & & & & & & & & & & & & & & & 5 & & & & & & & & & & & & & & \\
\hline GASTROPODA & & & & & & & & & & & & & & & & & & & & & & & & & & & & & & & & & & & & & & & & & & \\
\hline Tated ruflutbris & & & & & & & & & 15 & & & 6 & 1 & 3 & 1 & & 5 & & & 1 & 3 & 11 & 20 & 3 & 1 & & & & & & 3 & & & & & & & & & & & \\
\hline $\begin{array}{l}\text { 2Philine angasi } \\
\text { BIVALVIA }\end{array}$ & & & & & & & & & & & & & & & & & & & & & & & & & & & & & & & & & & & & & I & & & & & \\
\hline $\begin{array}{l}\text { BIVALVIA } \\
\text { Tellina deltoidalis }\end{array}$ & & & & & & & & & & & & & & & & & & & & & & & & & & & & 1 & 2 & 1 & 1 & & 3 & & & 43 & 2 & & 8 & & & \\
\hline $\begin{array}{l}\text { Arthritica helmsi } \\
\text { Venerpisisamal }\end{array}$ & 1 & 2 & 10 & 2 & 1 & 9 & 15 & 4 & 332 & 132 & 26 & 52 & 304 & 35 & 28 & 11 & 22 & 12 & 36 & 9 & 19 & 76 & 175 & 53 & 15 & 13 & 4 & 1 & & & & 12 & & & & & & & & & & \\
\hline $\begin{array}{l}\text { Veneripis anomala } \\
\text { BRYOZOA sp. or spp. }\end{array}$ & & & & & & & & & & & & & & & & & & & & & & & & & & & & $\mathrm{C}$ & & & & & & & & & & & & & & 2 \\
\hline AMPHIPODA & & & & & & & & & & & & & & & & & & & & & & & & & & & & & & & & & & & & & & & & & & \\
\hline $\begin{array}{l}\text { Limnoporeia kingi } \\
\text { Corophium sp. }\end{array}$ & & & & & & 1 & & 1 & & 31 & 1 & & 12 & & 1 & 14 & 4 & & & & 2 & & 3 & 4 & 1 & & 4 & & 2 & & & & & & & 1 & 2 & & 7 & & $\begin{array}{c}4 \\
10\end{array}$ & $\begin{array}{c}11 \\
3\end{array}$ \\
\hline 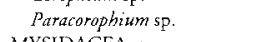 & & & & & & & & & 41 & 165 & 14 & & 129 & 6 & 5 & 34 & & & & & & 3 & 4 & 51 & 1 & 1 & & & & & & 37 & & & & & & & & & & \\
\hline $\begin{array}{l}\text { MYSIDACEA sp. nov. } \\
\text { DECAPODA }\end{array}$ & & & & & & & & & & & & & & & & & & & & & & & & & & & & & & & & & 2 & & & & & & & & & \\
\hline Amarinus sp. & & & & & & & & & 1 & & & & & & & & & & & & & & & & & & & & & & 1 & & & & & & & & & & & \\
\hline Macrophthalmus latiffons & & & & & & & & & & & & & & & & & & & & & & & & & & & & & & 1 & & & & & & & & & & 2 & & \\
\hline $\begin{array}{l}\text { ?Palaemonetes sp. } \\
\text { Paragrapsus gaimardii }\end{array}$ & & & & & & & & & & & & & & & & & & & & & & & & & & & & 2 & & & 1 & & & & & & & & & & & \\
\hline OSTRACODA sp. 1 & & & & & & & & & & & & & & & & & & & & & & & & & & & & ${ }^{2}$ & & & & & & & & & & & & & 2 & 13 \\
\hline OSTRACODA sp. 2 & & & & & & & & & & & & & & & & & & & & & & & & & & & & & & & & & & & & & & & & & & $\mathrm{i}$ \\
\hline OSTRACODA sp. 3 & & & & & & & & & & & & & & & & & & & & & & & & & & & & & & & & & & & & 1 & & & 4 & & & \\
\hline TANAIDACEA & & & & & & & & & & & & & & & & & & & & & & & & & & & & & & & & & & & & & & & & & & \\
\hline $\begin{array}{l}\text { Synaptotannits sp. } \\
\text { CUMACEA }\end{array}$ & & & & & & & & & & & & & & & & & & & & & & & & & & & & & & & & & & & & & & & & & & 33 \\
\hline Dimorphosstlis coleffaxi & & & & & & & & & & & & & & & & & & & & & & & & 11 & & & & & & & & & & & & & & & & & & \\
\hline DIPTERA & & & & & & & & & & & & & & & & & & & & & & & & & & & & & & & & & & & & & & & & & & \\
\hline $\begin{array}{l}\text { Chironomidae sp. } 1 \\
\text { ASTERODEA }\end{array}$ & & & 1 & 1 & & & & & & & & & & & & & & & & & & & & & & & & & & & & & & & & & & & & & & \\
\hline $\begin{array}{l}\text { ASTEROIDEA } \\
\text { Pativella regularis }\end{array}$ & & & & & & & & & & & & & & & & & & & & & & & & & & & & 1 & & & & & & & & & & & & & & \\
\hline $\begin{array}{l}\text { Pattiella regulumis } \\
\text { Uniophora granifera }\end{array}$ & & & & & & & & & & & & & & & & & & & & & & & & & & & & & & & & & & & & & & & & & 1 & \\
\hline $\begin{array}{l}\text { STEICHTHYES } \\
\text { Unidentified pobiid }\end{array}$ & & & & & & & & & & & & & & & & & & & & & & & & & & & & & & & & & & & & & & & & & & \\
\hline Unidentified gobiid & & & & & & & & & & & & & & & & & & & & & & & & & & & & & & 1 & & & & & & & & ? & & & & \\
\hline Species Richness & 3 & 2 & 4 & 4 & 5 & 4 & 3 & 4 & 6 & 7 & 5 & 3 & 6 & 5 & 6 & 4 & 3 & 3 & 2 & 3 & 5 & 8 & 6 & 8 & 6 & 3 & 5 & 10 & 3 & 5 & 5 & 3 & 4 & 3 & 4 & 9 & 5 & 4 & 7 & 4 & 11 & 22 \\
\hline Total Abundance & 3 & 12 & 195 & 30 & 129 & 30 & 31 & 56 & 818 & 489 & 241 & 80 & 453 & 96 & 54 & 62 & 31 & 26 & 43 & 11 & 44 & 108 & 215 & 133 & 22 & 15 & 20 & 15 & 5 & 7 & 7 & 54 & 11 & 4 & 10 & 90 & 20 & 12 & 31 & 5 & 69 & 212 \\
\hline
\end{tabular}


Table 2

The relationship (in terms of linear correlations) between species richness, total abundance, and various parameters of the sediment

\begin{tabular}{lcccccccc}
\hline & & Depth & Conductivity & Redox $^{*}$ & LOI $^{*}$ & $\%$ clay & \% quartz & $\mathrm{pH}^{*}$ \\
\hline Species & $(\mathbf{r})$ & 0.03 & 0.10 & 0.66 & 0.49 & 0.07 & 0.15 & 0.47 \\
Richness & $(\mathrm{n})$ & $69 \mathrm{~ns}$ & $69 \mathrm{~ns}$ & $65^{\$}$ & $64^{\$}$ & $58 \mathrm{~ns}$ & $69 \mathrm{~ns}$ & $65^{\$}$ \\
& & & & & & & & \\
Total & $(\mathbf{r})$ & 0.24 & 0.42 & 0.23 & 0.46 & 0.14 & 0.21 & 0.17 \\
Abundance & $(\mathrm{n})$ & $69^{\ddagger}$ & $69^{\$}$ & $65 \mathrm{~ns}$ & $64 \$$ & $58 \mathrm{~ns}$ & $69 \mathrm{~ns}$ & $65 \mathrm{~ns}$ \\
\hline
\end{tabular}

$\mathrm{r}=$ correlation coefficient. $\mathrm{n}=$ sample size. ( Total data set sample size $=69$.) $\mathrm{ns}=$ not significant.

*Values are missing at a few sampling stations.

tValues in the mixing zone have been excluded due to the trace quantities recorded.

Significant at the 0.05 level.

$\checkmark$ Significant at the 0.001 level.

(1) The Derwent estuary may be naturally depauperate in its faunal composition, or it may be part of a biogeographical province in which estuaries are depauperate faunistically.

(2) The Derwent survey may not have sought a complete longitudinal profile of benthic invertebrates, including fully freshwater and/or marine species; these constitute a high proportion of taxa found in estuaries.

(3) Seasonal variations in the fauna were not examined for the Derwent but were incorporated in the other studies, so that species absent from the Derwent estuary in late summer would not be represented in samples.

(4) Spatial variations in the estuary were not sought, so that obvious habitat variations, where the faunal composition might well have been different, were deliberately not sampled and, in fact, the sampling programme was designed to concentrate approximately two-thirds of the samples in sediments showing evidence of sludge.

(5) There were other differences in the sampling methodology in the studies (for instance, grab samples in this study compared to artificial substrates in Edgar (1990), and other methods more likely to collect very rare species).

(6) Environmental stress (i.e. pollution) may be more severe in the Derwent than in the other estuaries, resulting in the elimination of species, or rendering them very rare and unlikely to be detected in such a survey.

None of these possible explanations can be discarded as unlikely. The first is impossible to test, in the absence of baseline data (faunal lists) on the Derwent estuary prior to the development of the Hobart metropolitan area and the introduction of major polluters, and in the absence of data from nearby estuaries such as the Huon estuary.

The longitudinal distribution of invertebrates in an estuary is somewhat characteristic, with species richness decreasing as salinities rise at first, but then showing a tendency to increase markedly with further salinity rises to full seawater concentrations (see Kennish 1990). Thus, by not sampling the extremes where the majority of taxa are found, this study could have seriously underestimated the total number of species present in the estuary. For instance, no samples were taken from above the effluent outfall at Boyer (corresponding to, coincidentally, the upper extremity of the inland penetration of the salt-wedge). Despite the decreased species richness in the middle parts of an estuary, the density of the taxa present there can be great; these high abundances are often attributed to the reduction in the number of species competing for a limited food supply (Kennish 1990). The high abundances found in this study, around the naturally-occurring mud flats and shallower areas on both sides of the Bridgewater causeway, may be due in part to this tendency, apparently unaffected by the mechanical wood fibre which is carried in deeper parts of the estuary.

Points 3, 4 and 5 above, represent the most serious methodological limitations of the present study. They cannot be tested without further surveys in other seasons and in habitats not actively sought in this study, such as in seagrass communities and on hard substrata, and by using a variety of collecting techniques.

The question of environmental degradation in the Derwent is obviously the focus of this work. Traditional methods of examining benthic samples and estimating environmental stress, such as selecting a faunal group which is known to be sensitive to pollution, recording deviations of the log-normal distribution, or using the abundancel biomass comparison method (Meire \& Dereu 1990) are all inappropriate in this case. This is because of the lack of prior knowledge of the fauna, the large number of samples which were totally devoid of species, and the small number of samples taken at each station (thereby reducing the replicability). In addition, the samples were collected from across an ecocline from the inland intrusion of a salt-wedge to a predominantly marine situation. Only the incidental observations of the most common species are useful in this regard: Orthoprionospio cirriformia occurs in places in very high densities, sometimes in the presence of mechanical wood fibre and the absence of other benthic invertebrates, and it appears to be able to tolerate highly negative levels of redox potential. The presence of one or two small opportunistic species, which are both numerical and biomass dominants is strong circumstantial evidence for a disturbance (i.e. pollution perturbation) in a community (Warwick 1986).

The presence of extensive sediment samples with a series of environmental variables, indicative of environmental degradation, allows a number of postulations to be made regarding the benthic fauna of the Derwent, and these can be used in the future as the hypotheses for more detailed analysis. Thus: 
(1) The strong correlations between species richness, redox and $\mathbf{L O I}$ indicate that the presence of wood fibre, with its concomitant smothering effect, and reduction of sediments, due toaction of anaerobic bacteria, result in an often complete faunal eclipse, not only in deeper but also in surface portions of the sediment. In addition, sediments which are strongly reducing convert mercury into a methylated form (So 1979) which is extremely toxic to animal life. Thus, sediments with wood fibre and heavy metals, like mercury, may act as a significant deterrent to most potential colonising invertebrates, as well as being toxic to those already occupying them.

(2) The very high densities of invertebrates on either side of the Bridgewater causeway appear to be related to the shallow depth of the water, in which sediments had a lower conductivity and a comparatively lower wood fibre content. These high densities of invertebrates have significant conservation value. Extensive bird colonies (Blackhall 1988) utilise the food resources in these high density areas. Any change to the buoyancy of effluent from ANM at Boyer, or nutrient status of the upper Derwent estuary, may have a significant detrimental effect on the shallow water ecology in these areas.

(3) On the basis of the present study the effects of other sources of pollution well below Dogshear Point cannot be dissociated from the effects of the presence of mechanical wood fibre, even though many of the sites sampled have clearlydepauperate faunal communities and often high levels of mechanical wood fibre.

\section{ACKNOWLEDGEMENTS}

This work formed part of the Derwent River Sludge Study, funded by the Department of Environment and Planning, Pasminco Ltd and Australian Newsprint Mills Ltd.

We are most grateful to those researchers who kindly identified invertebrates, namely Liz Turner (Mollusca), Robin Wilson (Polychaeta), Russell Hanley (Polynoidae), Alison Green (brachyuran crustaceans), Gwen Fenton (mysid crustaceans) and Gary Poore (Amphipoda, Tanaidacea, Cumacea). Andrew Dumphy helped with sample sorting. The Marine Board of Hobart provided information on tides and water heights. Selection of sampling sites and coordination of the collection of samples was undertaken by Christian Garland. We appreciate the critical comments of Graham Edgar on an earlier version of the manuscript.

\section{REFERENCES}

ANON., 1989: DERWENT RIVER SLUDGE STUDY PHASE 1. Tech. Rep. Dep. Environment, Hobart.

BíACKHALL, S.A., 1988: A survey to determine waterbird usage and conservation significance of selected Tasmanian wetlands State II. Occ. Pap. 16 Dep. Wildl. Heritage, Hobart.
Bloom, H. \& Arting, G.M., 1977: Heavy metals in the Derwent estuary. Environ. Geol. 2: 3-22.

Davies, P.E. \& KaLISH, S., 1989: Warer quality of the upper Derwent estuary, Tasmania. Occ. Rep. 89-03, Inland Fisheries Commission.

Edgar, G., 1990: Hydrological and ecological survey of the Port Davey/Bathurst Harbour estuary 1988-1989. Rep., Tasm. Dep. Parks, Wildl. \& Heritage.

Gariand, C., Horwitz, P. \& Holloway, P.E., 1990: Distribution and characterisation of wood fibre-rich sludge in the Derwent River estuary. DERWENT RIVER SLUDGE STUDY PHASE 2, vol.2B. Tech. Rep. Dep. Environ., Hobart.

GRAY, J.S., 1981: Detecting pollution-induced changes in communities using the log-normal distribution of individuals among species. Mar. Poll. Bull. 12: 173-176.

Guller, E.R., 1955: Observations on the hydrology of the River Derwent, Tasmania. Pap. Proc. R. Soc. Tasm. 89: 65-80.

JONES, A.R., 1987: Temporal patterns in the macrobenthic communities of the Hawkesbury Estuary, New South Wales. Aust. J. Mar. Freshw. Res. 38: 607-624.

Jones, A.R., Watson-Russell, C.J. \& Murray, A., 1986: Spatial patterns in the macrobenthic communities of the Hawkesbury Estuary, New South Wales. Aust. J. Mar. Freshw. Res. 37: 521-543.

KENNISH, M.J., 1990: ECOLOGY OF ESTUARIES. VOLUME II. BIOLOGICAL ASPECTS. CRC Press, Boston.

MatThews, J.H., 1979: An investigation of the effects of the effluent from ANM on the upper Derwent estuary. Unpubl. rep., ANM Ltd, Boyer, Australia.

MсСомв, A.J. \& Lukatelich, R.J., 986: Nutrients, and plant biomass in Australian estuaries, with particular reference to south-western Australia. AUSTRALLAN LIMNOLOGY. CSIRO, Melbourne/Junk, Dordrecht.

Meire, P.M. \& Dereu, J., 1990: Use of the abundance/biomass comparison method for detecting environmental stress: some considerations based on intertidal macrozoobenthos and bird communities. J. Appl. Ecol. 27: 210-223.

Poore, G.C.B., 1982: Benthic communities of the Gippsland Lakes, Victoria. Aust. J. Mar. Freshw. Res. 33: 901-915.

Poore, G.C.B. \& Kudenov, J.D., 1978: Benthos of the Port of Melbourne: the Yarra River and Hobsons Bay, Victoria. Aust. J. Mar. Freshw. Res. 29: 141-155.

RAINER, S., 1981: Temporal patrerns in the structure of macrobenthic communities of an Australian estuary. Estuarine, Coastal and Shelf Science 13: 597-620.

So, C.L., 1979: Mercury-water interactions in the estuarine environment. Mar. Poll. Bull. 10: 334-337.

SPRATT, P., 1976: An investigation of the estuary of the Derwent River with predictive reference to the mid-littoral zone of the rocky shores on each bank. Centre for Environmental Studies, University of Tasmania.

WARWICK, R.M., 1986: A new method for detecring pollution effects on marine macrobenthic communities. Mar. Biol. 92: $557-562$.

Zar, J.H., 1974: BIOSTATISTICAL ANALYSIS. Prentice-Hall, New York. 